\title{
ACORDAM E SONHAM UMA APROXIMAÇÃO POLIFÔNICA AO ROMANTISMO FREIRIANO ${ }^{1}$
}

\author{
WAKE UP AND DREAM \\ A POLYPHONIC APPROACH TO FREIRIAN ROMANTICISM
}

Resumo: A biografia de Paulo Freire serve como uma bússola à sua práxis pedagógicas. no presente estudo, excertos dos seus textos e das suas entrevistas constituem um conjunto de textos que são submetidos à análise para daí se deduzir momentos que foram chave na vida dele. também deduz, neste trabalho, que o filósofo e educador pernambucano pertence à linha nobre dos românticos e que os seus antecessores ideológicos incluem Jean-Jacques Rousseau E William Morris. o modo como freire trata as questões humanas o colocam diametralmente na posição antagônica a qualquer tipo de conservadorismo ou neoconservadorismo.

Palavras Chave: Utopia. Romantismo. Conscientização. Colonização. Dialogo.

Abstract: Paulo Freire's biography serves as a compass to his pedagogical praxis. In the present study, excerpts of his texts and interviews constitute a set of texts that are subjected to analysis in order to deduce moments that were key in his life. It also deduces from this work that the Pernambuco philosopher and educator belongs to the noble line of the romantics and that his ideological predecessors include Jean-Jacques Rousseau and William Morris. The way Freire treats human issues put him diametrically in the antagonistic position to any kind of conservatism or neoconservatism.

Key-words: Utopia. Romanticism. Conscientization. Colonization. Dialogue.

Para citar - (ABNT NBR 6023:2018)

LOWNDS, Peter. Acordam e sonham uma aproximação polifônica ao romantismo Freiriano. Eccos Revista Cientifica, São Paulo, n. 52, p. 1-20, e17097, jan./mar. 2020. Disponível em:

https://doi.org/10.5585/eccos.n52.17097. 


\title{
1 Contexto histórico
}

Paulo Freire é tido por muitos de seus analistas mais argutos como um pensador com raízes cristãs, existenciais e marxistas (v., entre outros, BEISIEGEL, 1982; BRANDÃO, 1980; GADOTTI, 1989; TAYLOR, 1993 e TORRES, 1979). Contudo, pode-se inclúi-lo em outra corrente de pensamento: a utópica/romântica. Freire abre Pedagogia do oprimido com um enigma utópico:

\begin{abstract}
La violencia de los opresores, deshumanizándolos también, no instaura otra vocación, aquella de ser menos. Como distorsión del ser más, el ser menos conduce a los oprimidos, tarde o temprano, a luchar contra quien lo minimizó. Lucha que solo tiene sentido cuando los oprimidos en la búsqueda por la recuperación de su humanidad, que deviene una forma de crearla, no se sienten idealísticamente opresores de los opresores sino en restauradores de la humanidad de ambos. Ahí radica la gran tarea humanista e histórica de los oprimidos: liberarse a sí mismos y liberar a los opresores. Estos, que oprimen, explotan y violentan en razón de su poder, no pueden tener en dicho poder, la fuerza de la liberación de los oprimidos ni de sí mismos. Sólo el poder que renace de la debilidad de los oprimidos será lo suficientemente fuerte para liberar a ambos. (1970, p. 39).
\end{abstract}

Como é possível que a debilidade, a fraqueza de gente pobre e até invisível à maioria da população fará o renascimento de um poder restaurativo à humanidade de todos e todas - ricos e pobres, opressores e oprimidos? O autor desta declaração deve estar sonhando!

\begin{abstract}
Los oprimidos, que introyectando la "sombra" de los opresores siguen sus pautas, temen a la libertad, en la medida en que ésta, implicando la expulsion de la "sombra", exigiría de ellos que "llenaron" el "vacío" dejado por la expulsión, con "contenido" diferente: el de su autonomía. El de su responsabilidad sin la cual no serían libres. La libertad, que es una conquista y no una donación, exige una búsqueda permanente. [...] No es idea que se haga mito sino condición indispensable al movimiento de búsqueda en que se insertan los hombres como seres inconclusos (FREIRE, 1970, p. $43-44)^{2}$.
\end{abstract}

Numa época em que as doações são incrivelmente bem compensadas - todo magnata possui uma fundação benévola à sua causa favorita e livre de impostos - e as 'conquistas' da cidadanía, da segurança sexual, e da liberdade de expressão (para mencionar somente três de uma lista longa), especialmente quando se trata de gente ordinária, são crescentemente perigosas, somente um romântico desvairado, ou um Quixote míope, atacaria os moinhos poderosos!

Paulo Freire escreveu Pedagogia do oprimido como um refugiado politico em Santiago de Chile, nos meados dos anos 60, após o golpe militar que suplantara o regime democrático do Presidente João Goulart e o substituíra pela ditadura duradoura dos generais. O livro é um resumo filosófico das suas pesquisas como o ideólogo pedagógico do Movimento da Cultura Popular (MCP) que nasceu, como ele, em Recife, Pernambuco. Alvo de acusações de subversão 
e traição à pátria, Freire foi encarcerado e fugiu do Brasil rumo à Bolivia. Depois, foi para o Chile, EUA e Suíça, onde se tornou testemunha e assessor ao desenvolvimento pós-colonial de paises africanos e latino-americanos. Suas experiências forneceriam material para dúzias de livros, palestras, e seminários, que transformaram um simples professor de educação universitária de uma das regiões mais pobres do hemisfério num pedagogo e filósofo mundialmente conhecido como um representante do humanismo esclarecido.

Na época, João Francisco de Souza, ${ }^{3}$ um rapaz de dezesseis anos de idade, era um voluntário no $\mathrm{MCP}$, ajudando organizar espetáculos gratuitos nas cinco Praças da Cultura da cidade de Recife onde pessoas de todas as camadas da sociedade podiam assistir e discutir filmes, teatro, música e cultura com artistas e intelectuais regionais. O diálogo pós-exibição entre os produtores e a plateia era tão engajado que Freire criava os Círculos da Cultura. Inicialmente, os círculos não contiveram nenhum componente de alfabetismo. Contudo, em 1961, quando Freire tornou-se o primeiro diretor do Departamento da Extensão Cultural na Universidade de Recife, ele e seus alunos começaram buscar o que chamaram de palavras geradoras e temas geradores nos povoados da classe trabalhadora no centro e nas periferias da cidade. Estes vocábulos principais serviram de base a um modo dialógico de ensinar e aprender: as bases do idioma e da cultura do Brasil acabaram por constituir os fundamentos do Método Paulo Freire.

Enquanto a sua notoriedade aumentava, o Método tornou-se o arquétipo da campanha nacional de alfabetização instituída nas últimas semanas do "Governo Jango" (nome dado à administração do Presidente João Goulart). Paulo Freire viajou à Brasília, a nova capital da nação, para supervisionar a difusão dos seus preceitos pedagógicos. Mas, todo o avanço na alfabetização, terminou abruptamente com o golpe militar de primeiro de abril de 1964, com a ocupação da matriz do MCP - um centro popular da informação, com uma grande coleção de livros, documentos e arte acumulada pela liderança do movimento (Germano Coelho, Chico Weber, Anita Paes Barreto, Abelardo da Hora, Paulo Rosas e Paulo Freire) - pela tropa e a queima total da Biblioteca Brasiliana.

As décadas 60 e 70 do século XX foram potencialmente revolucionárias e a acolhida do Freire pelo Conselho Mundial das Igrejas na Suíça lhe permitiu seguir projetos cujos fins tiveram appeal sem qualquer agenda ecumênica. Finalmente, quando a anistia foi lhe concedida quinze anos depois da sua saída apressada do Brasil, Freire regressou à terrinha. Um dos seus patrícios de exílio chileno, Almino Affonso, lhe deu "Boas Vindas Ao Brasil," num texto publicado na Folha de São Paulo no dia 8 de agosto de 1979. Aponto alguns trechos: 
[...] A fascinante experiência do professor Paulo Freire remonta a 1962, primeiro em Recife e no Rio Grande do Norte. Mas o seu nome ganhou dimensão nacional quando, no segundo semestre de 1963, a convite do ministro da Educação Paulo de Tarso, ele assumiu a ingente tarefa de comandar a campanha de alfabetização de adultos. $\mathrm{O}$ quadro: 16 milhões de analfabetos, a partir da faixa etária dos 14 anos, ensombreciam o processo de democratização da sociedade. Em termos politicos, presumia-se que esse contingente humano tendia a apoiar uma plataforma de transformações sociais: mas a Constituição Federal o excluía do corpo eleitoral. Por tudo isso, a extensão do direito de voto aos analfabetos converteu-se numa das exigências democráticas mais sentidas. Contudo, a solução era precária, insatisfatória. Não resolvia o problema social e, do ponto de vista político, era uma faca de dois gumes: podia redobrar as pressões pelas reformas estruturais; mas também podia, sobretudo no campo, ampliar as bases de sustentação das lideranças mais conservadoras.

Nesse quadro político o professor Paulo Freire começou a aplicar, em escala nacional, o método psicossocial. A rapidez dos resultados impressionava a todos e a consciência do educando se convertia, no processo de aprendizagem, num crítico social. Ao longo de 1964, o plano contemplava a alfabetização de 2 milhões de cidadãos. Uma vez montados os "círculos" na quase totalidade dos Estados, estimava-se que, até 1965, 5 milhões de adultos teriam se alfabetizado. [...] As conseqüências políticas que estavam sendo gestadas nesse processo saltam aos olhos. Em Pernambuco, o eleitorado (até então de 800 mil votantes) chegaria à casa de 1.300 mil. E, na maioria dos Estados, o número de eleitores dobraria.

A cidadania resultante romperia o predomínio eleitoral dos setores conservadores em quase todo o País. Aí está um dos aspectos da crise de 1964 sobre o qual nunca se fala. $[\ldots]$

O professor Paulo Freire se transformou no alvo de constantes ataques, no Parlamento e na imprensa, dos porta-vozes do obscurantismo. Como assinala Francisco Weffort, "não podiam compreender que um educador católico se fizesse expressão dos oprimidos e menos ainda podiam compreender que a cultura levada ao povo pudesse conduzir à dúvida sobre a legitimidade de seus privilégios." É evidente que o professor Paulo Freire, pela essência mesma de seu pensamento, não induzia no alfabetizando a opção política; mas era irrecusável que, através da conscientização, lograda através da livre associação de causa e efeito que o diálogo propiciava, o educando visualizava a sua própria identidade social e assumia a crítica da sociedade que o explorava. Ao fim e ao cabo, a miséria e o analfabetismo não são caras diferentes da mesma moeda? (GADOTTI et al., 1996, p. 192-193).

\section{Antecessores Românticos}

No seu livro William Morris: romantic to revolutionary (1955), E. P. Thompson retrata um antecessor empolgante da segunda metade do século XIX (1834-1896), um fundador do movimento britânico de artes e artefatos que se tornara marxiano:

O primeiro dever dos revolucionários, Morris decidiu (após sua leitura do Capital de Marx) foi "exprimir seu descontentamento e esperança sempre e onde quer que seja." Descontentamento e esperança - as palavras foram cuidadosamente escolhidas. Da origem classe mediana, confortável no seu ambiente, sua rebelião contra o capitalismo foi o resultado de um asco moral em vez da experiência direta com a pobreza e a opressão. Ele pôs a questão nos termos mais simples numa carta ao C.E. Maurice: "Considerando questões sociais e políticas tenho uma só regra: quando penso da condição de qualquer grupo de pessoas, me perguntarei, 'Como você aguentaria essa? O que sentiria se fosse pobre e se existisse neste sistema?"'4 (THOMPSON, 1955, p. 357) 
Paulo Freire perguntara e respondera à mesma pergunta no fim da vida dele (veja na secção abaixo). Frantz Fanon, o médico e autor argelino, que trabalhava nos hospitais norteafricanos durante a guerra franco-argelina, escrevia sobre o sofrimento dos descendentes dos escravos nas colônias europeias. Morreu de leucemia na idade de 36 em 1961, meses após Os esfarrapados do mundo ser publicado:

\footnotetext{
Sob o sistema colonial, uma classe média que acumula o capital é um fenómeno impossível. Então, precisamente, pareceria que a vocação histórica de uma classe média nacional autêntica num país subdesenvolvido seja repudiar sua própria natureza se fosse burguesa, quer dizer se fosse o instrumento de capitalismo, e de se oferecer como o escravo prestativo daquele capital revolucionário que é o povo [...] de trair a vocação que o destino tivera lhe marcado e meter-se com o povo na escola: em outras palavras, botar ao dispor do povo o capital intelectual e técnico que tinha agarrado quando passava pelas universidades coloniais. ${ }^{5}$ (FANON, 1988, p. 150).
}

Paulo Freire traiu a vocação que o destino tinha lhe marcado quando repudiou a carreira de advogado para ser educador. Como um representante autêntico da classe média de um país subdesenvolvido, ele'se metia na escola com o povo e botava ao seu dispor o capital intelectual e técnico que agarrara das universidades pernambucanas pós-coloniais. Se repudiasse ou não sua natureza burguesa é um assunto aberto à opinião. No capítulo inicial da Pedagogia do oprimido, Freire cita Fanon sobre a violência interna do "homem colonizado que manifestará sua agressividade ... contra seu próprio povo.” Ele pode não ter descoberto a obra de William Morris. Contudo, os dois são, cem anos e um hemisfério a parte, camaradas na mesma tradição.

Morris, segundo Thompson, "tomaria certas proposições marxistas como seu ponto de partida mas usou-as como um trampolim de onde a sua imaginação fez um salto utópico" (op. cit., 1955, p. 421). O mesmo poderia ser dito de Paulo Freire; um dos seus saltos utópicos era a percepção que todo o mundo tem uma "vocação ontológica" de se tornar o sujeito da sua própria história.

A conscientização canaliza a percepção crescente da subjetividade pessoal; reconhecemos que somos seres inseridos na história com uma variedade de escolhas existencias a nosso dispor. Paulo Freire nunca se cansou de estudar essas escolhas junto com as ilusões e os vícios que cultivamos para anestesiar as feridas que geraram; Freire acreditava que, se cultivarmos e compartilharmos a nossa autoconsciência e a nossa experiência, criamos oportunidades de superar as restrições e "situações limites" impostas por todo tipo de opressão. É o cerne da sua mensagem, uma amálgama sabida de amor e razão que fizera a sua campanha pela pedagogia dialógica tão atraente. Há 86 anos, o psicanalista austríaco Otto Rank escreveu: 
Para o romântico, sua própria experiência parece ser um preliminar essencial à produtividade. [...] O romântico deve justificar sua vida e sua experiência pelo trabalho dele e, além disso, deve ter a testemunha de sua vida para justificar sua produção. ${ }^{6}$ (1932, p. 48 e 51).

\title{
3 Em Busca do "Eu"
}

Os anos que Paulo Freire trabalhara como Diretor (1947-1954) e Superintendente (19541957) da Educação e Cultura no Serviço Social Industrial (SESI) representam o eixo da sua carreira pré-universitária. Encarregado da educação moral dos/das adultos/as, professor Freire ficou atordoado quando notou a relutância dos seus alunos/as de entrarem em diálogo com seus educadores e engajarem uns com outros no diálogo:

\begin{abstract}
Aos educadores
Considerações em torno do temário: Disciplina

Já ficou bem claro que os Círculos de Pais e Professores não devem ser formais, discursivos. Neles, realmente, o que se há de fazer é levar o grupo dos pais ao debate. É levar os pais a "arrancar" de dentro de si respostas às perguntas do temário, repetidas pausadamente pelo orientador da reunião.

Obter dos pais que dêem respostas às perguntas, de acordo com o seu conhecimento de senso comum. Caberá ao educador, depois, fundado nestas respostas, dar soluções de saber científico.

O assunto central desta reunião é Disciplina. Falar, porém, sobre disciplina, mesmo em linguagem acessível, em forma de palestra não seria o suficiente para interessar ou prender a maioria dos ouvintes, pessoas cansadas de seus trabalhos diários (FREIRE, 2006, p. 80).
\end{abstract}

Finalmente, um trabalhador atrevido se levantou e respondeu:

Já temos ouvido umas palavras agradáveis do doutor Paulo Freire. Algumas delas estavam bastante simples para a gente compreender. Outras estavam mais complicadas. Mas acho que entendi a maioria. Agora quero perguntar um par de coisas pro doutor Paulo. O sinhô sabe onde a gente mora? O sinhô já entrou num mocambo da gente?" E começou a descrever seus barracos lastimáveis. Enumerou a falta de facilidades, o espaço extremamente inadequado para caber todos os seus corpos. Falou da inexistência de recursos para satisfazer as necessidades mais básicas. Falou do cansaço físico e da impossibilidade de sonhar com um futuro melhor. Queria me esconder na cadeira, tentei me afundar nela, achar algum buraco e me esvair ${ }^{7}$ (FREIRE, 1994, p. 24).

O trabalhador continua. Cataloga os detalhes do privilégio burguês do doutor Freire com tanta acuidade intuitiva e tão precisamente que "não havia nada de adicionar ou subtrair. Eis a minha casa; um outro mundo, espacioso e confortável" (ibid., p. 26-27).

Após a reunião, Freire se queixa "bem amargamente" à esposa, Elza: - "Não me entenderam.” Ela responde: - "Talvez seja você que não lhes entendeu, Paulo." Contudo, um sentido de impotência ameaça seu conforto. Freire confessa ter tido sete anos de depressões intermitentes, na faixa etária de 22 a 29 anos de idade. 
Essa falta de interesse no mundo, esse pessimismo ocorreu mais frequentemente durante a estação chuvosa quando viajaria à zona da mata para discutir seus problemas educacionais com as famílias das educadoras e dos alunos nas escolas do SESI (ibid., p. 28).

Ele afirma que, mesmo quando esteve em São Paulo para assistir uma conferência, a chuvarada paulistana não the afetara tanto. "O que faltara foi o verde das canaviais e o massapê, a argila negra do nordeste" (ibid., p. 29). Tendo ligado "suas depressões" à paisagem lamacenta, Paulo Freire regressa ao Jaboatão dos Guararapes 8 “em busca da [sua] infância”. No entanto, ele tentava ver as coisas pela lente positiva: "Precisava descobrir como esses elementos tinham a força de provocar minha depressão". Porém, lembranças perturbadoras sempre vinham à tona:

Parei em frente da casa em que tinha morado - a casa onde morreu meu pai na tarde crepuscular do 21 outubro de 1934. Revi o gramado longe que se estendeu diante da casa, onde jogámos futebol. Revi as mangueiras e os meus pés, meus pés embarrados, se arrastando na colina. Fiquei ensopado dos pés à cabeça. Pude ver, como numa tela, meu pai falecendo, minha mãe em estupefação, minha família perdida na tristeza.

Então fui ver certas áreas onde, mais da necessidade de fazer algo que pelo esporte, cacei passarinhos inocentes com um bodoque feito à minha mão que sempre tirei certinho.

Naquela tarde chuvosa, com o céu cor de chumbo sobre o brilho do terreno verde e o chão alagado, descobri o tecido da minha depressão, o caroço fundo, interno, oculto. Cavei a arqueologia da minha $\operatorname{dor}^{9}(1994$, p. 30).

\section{A Nona Carta a Cristina deixa claro que a morte do pai, Joaquim Temístocles, fora para}

Freire, com treze anos de idade, um momento chocante e decisivo.

Quando voltei ao quarto entre dezessete e dezessete horas e trinta minutos da tarde vi meu pai, ao esforçar-se para sentar-se na cama, gritar de dor, a face retorcida, tombar para trás agonizante. Nunca tinha visto ninguém morrer, mas tinha a certeza, ali, de que meu pai estava morrendo. Uma sensação de pânico misturado com saudade antecipada, um vazio enorme, uma dor indizível me tomaram e eu me senti perdido. Alguém me tirou do quarto e me levou para um outro canto da casa de onde ouvi, cada vez mais fracos, os gemidos de dor, tudo isso se acha fixado em mim, na memória de meu corpo, com a nitidez com que o peixe fossilizado se incorpora à pedra (1994b, p. 100).

"Só entre 1935 e 1936 houve uma real melhora", escreve ainda na Nona Carta, completando:

... com a participação efetiva de Armando, meu irmão mais velho, que conseguira um trabalho na Prefeitura Municipal do Recife, de [irmã] Stela, que recebeu seu diploma de professor do primeiro grau e começara a trabalhar e de [irmão] Temistocles, que andava o dia inteiro no Recife fazendo mandados para um escritório comercial (ibid., p. 102). 
Todo o mundo foi trabalhar, além de Paulo, cuja mãe convenceu o diretor de um bemconhecido colégio particular no Recife a admitir o filho mais franzino como bolsista. O futuro autobiógrafo está paralisado pela imagem no espelho: "Eu pobre, magro, desengonçado, feio" (ibid., p. 87). Talvez, matar "passarinhos inocentes" fosse um rito de passagem para este rapaz desajeitado à beira da virilidade. Ou, talvez, estivesse exprimindo sua ira e seu medo relacionados ao abandono simbólico da família pelo pai falecido. Era uma situação difícil, mesmo para o jovem adulto Paulo Freire:

\begin{abstract}
O que quero dizer é que, na sucessão de aprendizagens de que participamos, vai sendo enfatizado em nós o amor à vida ou o amor à morte. A maneira como nos relacionamos desde a tenra idade com os animais, com as plantas, com as flores, com os brinquedos, com os outros. A maneira como pensamos o mundo, como atuamos sobre ele; a malvadez com que tratamos os objetos, destruindo-os ou desprezando-os. $\mathrm{O}$ testemunho que damos aos filhos de desrespeito aos fracos, o desdém pela vida. Assim ensinamos e aprendemos a amar a vida ou a negá-la (ibid., p. 101).
\end{abstract}

O jovem Freire parece estar preso na dialética romântica: a luta entre a vida e a morte, entre a liberação e a reprodução, entre o oprimido e o opressor, o todo que os seres humanos incorporam a qualquer momento dado. Paulo, o adolescente matando passarinhos com seu bodoque, num ato fútil de revolta contra a morte do pai, fica preso num ponto crucial. No seu livro, A condição humana, Hannah Arendt postula Jean-Jacques Rousseau (1772-1778) como "o primeiro explorador articulado [e] teórico da intimidade", acrescentando que ele "chegou à sua descoberta por uma revolta não contra a opressão do estado senão contra a insuportável perversão do coração humano pela sociedade". Afirma, ainda, a pensadora: "O indivíduo moderno e seus conflitos intermináveis, sua incapacidade de sentir-se em casa na sociedade ou de viver completamente fora dela, seus sentimentos sempre inconstantes e o subjetivismo radical da sua vida emocional, houvera nascido nessa revolta do coração". E isso induziu Arendt ao que chamou:

\begin{abstract}
... a reação rebelde contra a sociedade durante qual Rousseau e os Românticos descobriram que a intimidade estivera dirigida contra as exigências niveladas do social contra que chamaríamos hoje de 'conformismo' inerente em cada sociedade. É importante se lembrar que essa revolta tivera lugar antes do princípio da igualdade, sobre o que temos culpado o "conformismo" desde de Tocqueville ${ }^{10}$, houvera tempo de firmar-se, ou no domínio social, ou no domínio politico ${ }^{11}$ (1998, p. 38-39).
\end{abstract}

\title{
4 A Palavra e o Mundo
}

Paulo Rosas, um camarada de Paulo Freire, desde o Movimento da Cultura Popular (MCP), dissera o seguinte sobre o amigo de toda a vida: 
De começo, vi que Paulo Freire era um educador em vez de um professor. [...] Ele concentrou muito mais atenção nos estudantes como pessoas do que no currículo [...] Para ele, a instrutora foi uma mediadora no processo de aprendizagem. Estava sempre consciente da complexidade do ato de aprender, a sua redução a uma experiência fundamentalmente pessoal e não transferível (1991, p. 9-10).

Compar-se isso às memórias de um outro amigo de Freire, o artista Adão Pinheiro, que estudara na Escola de Belas Artes de Recife, quando Paulo e Maria Tavares Miranda competiram pela cátedra da Filosofia de Educação, ali, em 1958. Adão descreveu Dra. Miranda como "a filósofa predileta dos católicos direitistas tradicionais" e acrescentou que "ela estava escolhida por um processo que tinha menos a ver com sua capacidade ou qualidade do que com a política e o poder. O poder é a cátedra mesma, não quem está na sua posse - tanto faz”. Este tipo de poder é semelhante à noção de "capital cultural," um leitmotif do sociólogo Pierre Bourdieu - que, numa época de convulsão e crise política, permite aos que a possuem "fugir à França e matricular numa escola de pós-graduação", enquanto os cortadores de cana-de-açúcar que se juntaram às Ligas Camponesas ${ }^{12}$ "estavam torturados, matados ou deixados de morrer de fome" pelo regime novo. Segundo Adão Pinheiro, o educador Paulo Freire era um produto nítido daquela era:

Todas as tradições, todas as paixões inspiradas pelo MCP lhe afetaram num processo de alquimia interna, o que o seu exílio exacerbara. Era uma pessoa visceralmente pernambucana que, repentinamente, se descobria enfrentando grandes ideias intelectuais, grandes embates de ideias, e fora transformado por isso. Como um pernambucano, uma pessoa que tem acesso ao universo dos pobres, uma pessoa oriunda de Jaboatão, está ensinado de pensar sobre a usina de açúcar e a rua, não sobre a empregada doméstica. Paulo fora capaz de ajustar a sua ótica e ver todo mundo (excerto da nossa entrevista, em 9 de julho, 2004).

Uma dessas adaptações óticas ocorrera na privacidade da biblioteca caseira de Paulo Freire, em Recife. Ele descrevera a situação no decorrer de uma entrevista que dera à Revista Risk, em Genebra (Suíça), em 1970:

Freire: Do meu ponto de vista, a educação para a liberdade implica exercício constante, permanente, da conscientização que se volta para si mesma e para sua relação com o mundo, tentando encontrar razões que expliquem e esclareçam a situação concreta do homem no mundo. Mas, não é suficiente. É importante fazer ver que a reflexão não é suficiente para o processo de libertação. Necessitamos da praxis ou, em outras palavras, necessitamos transformar a realidade em que nos encontramos. Mas, para transformar a realidade, para desenvolver minha ação sobre a realidade, transformando-a, é necessário conhecer a realidade. Por isso, em minha praxis, é necessário que haja constante unidade entre minha ação e minha reflexão. [...]

Risk: Poderia exemplificar?

Freire: Há um bom exemplo da época em que eu estava pensando (no Brasil) na possibilidade de desenvolver um método que possibilitasse que os analfabetos aprendessem, facilmente, a ler e a escrever. Eu estava estudando e refletindo em minha biblioteca (nunca contei isso antes, é a primeira vez) e pensei que a melhor forma não 
era desafiar a mente crítica, a conscientização crítica do homem e (é muito interessante notar agora a mudança que fiz) ... tratei de colocar, na conscientização das pessoas, alguns símbolos associados com palavras sem, entretanto, desafiar sua consciência. Voltar, então, na segunda fase, e desafiar criticamente esses conceitos para redescobrir a associação entre certos símbolos e palavras para, assim, recolher as palavras, recolher símbolos e palavras. Lembro-me de ter convidado uma boa mulher-uma camponesa analfabeta - que trabalhava em nossa casa como cozinheira. Num domingo, disse-lhe: "Olhe, Maria (era seu nome), tenho pensado em começar um jeito novo de ajudar as pessoas que não sabem ler e preciso de ajuda. Você poderia me ajudar nesta procura?" Ela disse: "Sim”. Levei-a até minha biblioteca. Lá, projetei uma foto de um menininho, sob a qual estava escrita a palavra menino. Perguntei-lhe: "Maria, o que é isto?" Ela disse: "É um menino". Projetei outra foto com o mesmo menino, porém, na ortografia da palavra menino, não havia a sílaba do meio, ou seja, meno em vez de menino. Perguntei-lhe: "Maria, falta alguma coisa?" E ela me disse: "Ah, sim, falta a parte do meio". Sorri e mostrei-lhe outra foto do mesmo menino faltando, entretanto, na palavra, a última sílaba, meni. Perguntei-lhe: "Falta alguma coisa?" "Sim, a última parte". Discutimos, conversamos durante mais ou menos quinze minutos sobre situações diferentes de menino: menino, meno, mino, meni, etc., e ela, a cada vez, captava a parte que estava faltando. Disse-me, então: "Olhe, estou cansada. É muito interessante, mas estou cansada". Ela trabalhava o dia inteiro mas, com 10 ou 15 minutos de trabalho intellectual, cansou-se. O que é normal. Entretanto, ela me perguntou: "Acha que posso ajudar?" E eu lhe disse: "Sim, você me ajudou muito porque você me fez mudar a minha forma de pensar". Ela acrescentou: "Obrigada".

Depois disso, ela saiu de minha biblioteca e, cinco minutos depois, me trouxe uma xícara de café. É fantástica a capacidade de amar (TORRES, 1979, p. 30-32).

Karl Marx morreu em 1883. William Morris, que se juntara ao Partido Socialista Britânico naquele mesmo ano, não o conheceu. Mas o colaborador de Marx, Friedrich Engels (1820-1895) conheceu Morris. Segundo E.P. Thompson, "Engels the desprezara como "um artista entusiástico e rico mas um socialista sentimental". Thompson postula que "a revolta inicial de Marx fosse pertinente à tradição romântica"; contudo, enquanto "cresceram as tendências para determinismo e positivismo", após a morte do autor do livro Das Kapital, "a crítica romântica do capitalismo [...] tornara a ser suspeita como 'moralismo' e 'utopismo"” (ibid., 1955, p. 249). William Morris voltara do utopismo clássico pelo que estivera obcecado, com a construção de modelos jurídicos e políticos para um discurso heurístico que, hoje, poderia ter mais com "estratégias de visualização": aprendendo focar e refinar a vontade, a ambição, o desejo. Morris desejara algo não tão diferente do que Hannah Arendt ao descrever como o interesse fundamental de Jean-Jacques Rousseau: a relação próxima entre o social e o íntimo. Rousseau foi o avô filosófico da florescência breve (nove semanas, do dia 18 de março até o dia 27 de maio de 1871) da Comuna de Paris. Um século depois da publicação do seu tratado, Émile ou sobre educação, William Morris esteve apaixonado pela ideia de uma Sociedade de Iguais e, num ensaio de 1894 intitulado “Como Viveremos Então?”, declarou: "Meu socialismo iniciara-se onde aquele [dos comunardos franceses] terminara, com um desejo intenso pela igualdade completa da condição para todos e todas". E.P. Thompson, seu biógrafo dos meados do século XX, tratou a paixão utópica de Morris com humor, ternura e compaixão: 
A análise do Romantismo e da sua trajetória na vida de Morris: a trajetória desde o Romantismo profundamente subjetivo de Keats (cuja aspiração, negada de realização, circulara entre a integridade do artista e o artefato ideal da Beleza). [...] em que todos os valores do individualismo sujetivo estiveram envenenados pela mancha da mortalidade. [...] Morris, como um utopiano e um moralista, nunca pudera estar assimilado pelo Marxismo, não por causa de alguma contradição de propósitos mas por que não se assimilara o desejo ao conhecimento, e por que a vontade de fazê-lo confundira dois princípios operativos de cultura. [...] Marxismo requer menos uma reorganização de suas partes do que um sentido da humildade diante daqueles traços da cultura que não pudera nunca pôr em ordem. As moções do desejo puderam ser legíveis no texto da necessidade e puderam então se tornar sujeitas à explicação racional e à crítica. [...] Que poderia fazer o Marxismo então? Bem, sentar-se sobre sua própria cabeça em nome do coração do Socialismo. Se pode fechar um balcão na sua farmácia universal e parar de oferecer poções de análise para remediar as doenças do desejo. Assim, as iniciativas não-prescritivas de homens e mulheres comuns, que estão às vezes alienados e às vezes utópicos no fundo de si, também terão um pouco de folga ${ }^{13}$ (THOMPSON, 1955, p. 265).

Essa dialética mutável de desejo e conhecimento é terra conhecida de Paulo Freire. Agora, que a maioria dos balcões na farmácia universal de Marxismo está fechada, é cada vez mais claro que gente como William Morris e Paulo Freire são marxisantes. O Professor Cornel West, no prefácio ao livro Paulo Freire: um encontro crítico, editado por Peter McLaren e Peter Leonard (1992, p. xiv), escreveu: "Paulo Freire ousa pisar onde Marx recusou-se a caminhar - no terreno onde o amor revolucionário de seres humanos lutadores sustenta sua fé recíproca e mantém a esperança viva neles e na história”. Como Jean-Jacques Rousseau e William Morris, Paulo Freire é um socialista romântico cujos escritos, muitas vezes contêm, descrições íntimas de seres humanos em crise, incluindo a própria mãe:

Aprendi na minha infância atribulada e convivendo com a dor moral de meus pais, experimentada nas mais diversas situações e quase sempre "recheada" de uma linguagem desrespeitosa, sobretudo, é óbvio, quando o sujeito paciente era minha mãe, a ser ou a tomar-me intensamente sensível ao dever de respeitar quem se acha em situação de fraqueza ou de debilidade. Em situações assim, a mim me dói dizer ao outro, nem mesmo a mim próprio: é um mentiroso, é um golpista.

Quando, por exemplo, minha mãe, dócil e timidamente, pedindo desculpas ao açougueiro por não haver pago a ínfima quantidade de carne comprada na semana anterior, ao solicitar mais crédito para trezentos gramas a mais, prometia que pagaria as duas dívidas, na verdade ela não mentia nem tentava um golpe. Ela precisava acreditar que realmente pagaria. E precisava, de um lado, por uma razão muito concreta - a fome real da família; de outro, por uma questão ética - a ética de mulher de classe média cristã católica. E quando o açougueiro, zombeteiro, machista, a desrespeitava com seu discurso de mofa, suas palavras a pisoteavam, a destroçavam, a emudeciam. Tímida e esmagada, eu a vejo agora, neste momento mesmo, eu a revejo frágil, olhos marejando, deixando aquele açougue à procura de outro em que quase sempre se acrescentavam outras ofensas às já recebidas.

Não estou hoje como até mesmo à época não estava pretendendo que o açougueiro, às suas custas, financiasse a nossa crise. Não era e não é isso. O que me revoltava era o desrespeito de quem se acha em posição de poder a quem não o tinha. Era o tom humilhante, ofensivo, canalha, com que o açougueiro falava a minha mãe. A entonação de censura, de reprovação do discurso do açougueiro, que ele prolongava 
desnecessariamente e de forma que todos, no açougue, ouviam, me fazia um tal mal que, agora, preciso me esforçar para descrever a experiência.

Até hoje, nem digo duas vezes a uma pessoa o erro que cometeu, nem posso suportar que façam o mesmo comigo (FREIRE, 1994b, p. 63-64).

A transmutação da dor infantil à determinação adulta é um arquétipo literário. A explicação esmiuçada da própria infância dada por Freire, além de ser fascinante, é profundamente melancólica. Ele é herdeiro de uma estirpe mestiça (português, africano e indígena) que testemunhara, desde os primeiros anos do século XVI, a extração por atacado da riqueza natural de uma das regiões mais fecundas do planeta pelos escravos dos sujeitos leais à monarquía lusitana, que foram recompensados, em alguns casos, com a doação real de vastos terrenos chamados capitanias. A escravidão e a fome são educadoras poderosas e suas lições persistiram. Pedi ao meu informante, Adão Pinheiro, que distinguisse Paulo Freire e Gilberto Freyre, o autor de Casa-grande \& senzala (2001). Ele empregava o adjetivo "monolítico" para descrever Gilberto:

\begin{abstract}
Há algo mórbido sobre a inteligência pernambucana. Quando morre uma pessoa, uma outra toma seu lugar e adota as mesmas manias. Ambos, Paulo e Gilberto fizeram isso, distanciando-se. É pessoalmente desorientador sentar-se na cátedra do poder. Poderia vir a tentação de pô-la na cabeça! Mas isso não se pode fazer. Se os generais não o tivessem expulsado, Paulo teria sido o sucessor de Gilberto. Tiveram pequenos vícios em comum, como utilizar a terceira pessoa singular para referir a simesmo. Porque se exilou, Paulo podia enxergar Pernambuco com uma ótica distinta, não somente Pernambuco, mas todas as minoridades do mundo. [...] Não quero que Jesus Cristo sacrifique-se para mim. Não quero ver o sangue dele transformado em rubis derramados num corpo de marfim na parede de uma igreja barroca brasileira. Aquilo me dá asco. Existe uma dimensão onde se passa por algo transcendente. Quero ser o agente da minha própria transformação. Paulo entenderia isto (Trecho da entrevista, em São Paulo, em 9 de julho de 2004).
\end{abstract}

\title{
5 Mestres e Escravos
}

Segundo Charles W. Mills, um historiador anti-colonialista, citado por Danilo Streck, o Contrato Social de Rousseau tornou-se logo um Contrato Racial: "Os europeus tiveram o papel de mestre com o direito de reduzir todos os outros aos escravos" (STRECK, 2003, p. 80-81). O único romance que o tutor de Émile considera ser nutriente para seu aluno é Robinson Crusoé, escrito em 1719 por Daniel Defoe. Na relação entre Crusoé e seu criado, Sexta-Feira, gerações de jovens mestres aprenderam como amansar e escravizar indígenas "selvagens" "para prevenir qualquer ferido em qualquer hora" (ibid., nota de rodapé 17, p. 82). A última peça de Shakespeare, A Tempestade, de 1613, também fizera parte da lista de leituras aprovadas do Émile. A ação da peça desenvolvera numa ilha utópica. "Um escravo selvagem e deformado", Caliban, é o lacaio de Próspero, o exilado Duque de Milão. Caliban ilustra a distinção freiriana 
entre um idioma oficial e um dialeto quando repreende seu mestre: "You taught me language and my profit on't/Is I know how to curse/The red plague rid you/For learning me your language!" [Você me ensinou seu idioma e tirei proveito dele/Agora sei como lhe xingar/A praga vermelha lhe destrói/Para me ensinar seu idioma] (Ato I, cena ii, linhas 36-365). Numa polémica célebre, o escritor cubano Roberto Fernández Retamar propõe que a história latinoamericana seja repensada na perspectiva de Caliban e seus milhões de hermanas y hermanos que colhem café, cortam cana-de-açúcar e curtem tabaco por gerações inumeráveis de Prósperos opressivos, recebendo em troca quase nada (v. a nota de rodapé 11 deste texto). Paulo Freire bem conhecera a Educação e atualidade brasileira ${ }^{14}$ e tentara mudar o foco do conhecimento hegemônico, transmitido em numerosas lições bancárias, para uma pedagogia mais inclusiva e dialógica nos seus experimentos, antes da golpe do estado de 1964.

\section{Uma Vida Compartilhada}

Encontrei-me pela primeira vez com Danilson Pinto, em 2002, no Centro de Educação para Jovens e Adultos (CEJA) que se localiza em Peixinhos, um bairro recifense de classe trabalhadora, onde dava aulas de Arte e Cultura numa escola intermediária, para que as garotas e os garotos apreciassem e preservassem o artesanato rico, mas frágil, da localidade. Ele me falou da sua infância em Fortaleza, Ceará, seus anos difíceis durante a ditadura militar, seu primeiro emprego, sua vida de postulante na Ordem Salesiana, sua decisão de revogar seus votos e seu ofício subsequente de educador popular. Seu testemunho foi livremente dado, eloquente e saliente. Danilson é "um intelectual incorporado", segundo a definição de Antônio Gramsci: uma pessoa que dedica a vida ao seu povo e ainda pode afastar-se dele para melhor observar e analisar seus desafios e testemunhar seu progresso. Paulo Freire devia ter sentido isso, quando pedira que Danilson elucidasse a sua prática educativa num encontro videogravado, em fevereiro de 1996, durante sua última viagem para Recife e Olinda. Eis um trecho do diálogo que tiveram numa ponte pedestre que faz parte da favela Cabo Gato em Olinda:

PF: [...] Que achas dessas condições? Que podes me dizer para me ensinar, como Paulo Freire, o educador bem-conhecido? Diga-me algo do teu cotidiano, da perspectiva de um educador popular que convive com as crianças, os jovens e os adultos que emergem daqui. Ou aprendo a melhorar junto com um homem como tu, ou eu ... eu paro.

DP: Lhe ensinar? (ri) É bastante complexo, tudo isso. Venho aqui diariamente. Agora estamos fazendo uma Colônia de Férias e a juventude me pergunta, "Professor, vamos receber a merenda quando recomeça a escola regular? Pois a próxima Colônia é só em julho e vamos ter que 'ficar no rato'. É uma expressão que se usam aqui em vez de 'passar fome'.

PF: (sussurrando) Que coisa!

DP: [...] A ansiedade desse povo sofrido atua como um anticorpo que lhes ajuda sobreviver nessa miséria. 
PF: Entendo e concordo contigo. Por isso lhe digo se me puserem aqui, pois não possuo este anticorpo, morreria antes de tê-lo (ri), antes de criá-lo, não sobreviveria um mês nessa miséria como esse povo que o produz já há muito tempo. Se pode ver também quão injusto somos. Geralmente, a gente começa a ter medo da favela toda.

DP: Tá certo.

PF: Mesmo quando ele não o é, cada favelado, ainda visto de longe, pode ser um enemigo potencial.

Talvéz não o seja ao momento, mas possa tornar a sê-lo a qualquer instante.

DP: É isso.

PF: Estamos nos defendendo dele à primeira vista. E, mesmo se não o percebemos, enquanto a gente se proteja dele, é como se estivessemos lhe atacando.

DP: É uma coisa interessante e uma grande lição que se aprenda do povo que vive aqui: o conceito da solidariedade. Na sexta-feira, sábado e domingo passados, um grupo de jovens que se formou um conjunto deu um concerto chamado Rock Alternativo em Peixinhos para colher comida e roupa dos próprios habitantes.

PF: Dos próprios habitantes.

DP: Quer dizer, as pessoas que têm duas, dá uma. Elas têm um espírito de solidariedade. Não esperam ajuda dos outros

PF: Não, não, não.

DP: Tem que vir do povo mesmo.

PF: Do povo mesmo.

DP: Eles não saem daqui, fazem suas próprias campanhas internas. Distribuem e compartilham o que há. É uma missão sem precedente. Estou muito comovido de fazer parte de uma comunidade que segue o dito bíblico que "não há ninguém tão pobre que ela ou ele não tem nada para dar". Quer dizer, no meio de toda essa miséria, ainda existem pessoas com vontade de compartilhar. PF: Que têm vontade de compartilhar.

DP: Com outras e outros ainda mais necessitados.

PF: Exatamente.

DP: Posso ter muita necessidade mas tem gente ainda mais necessitada. Uma senhora me disse, enquanto enchia um pequeno recipiente de feijão, "Vou botar um pouquinho de feijão aqui pros vizinhos." "Já recebeste sua própria comida?" Perguntei-lhe. "Sim, sinhô! Acontece que tô necessitada mas há gente mais necessitada que eu." O espírito de solidariedade ainda está circulando e ventilando a comunidade. Creio que seja uma forma de...

PF: Por que é a dor que gera isto. Uma das coisas que nos deve muito interessar como educadores, educadores com o povo e não sobre o povo nessas conversas ao respeito do espírito da solidariedade, é de mostrar que ela não pode e não deve desaparecer, ainda se as causas dela, que sejam a dor e a miséria, desaparecerem. Entendes?

DP: Sim, sim.

PF: Poderíamos imaginar, por exemplo, e seria uma ilusão reacionária, uma reação traidora às pessoas como seres humanos, se pensarmos assim: 'agora que temos mais para comer, não precisamos compartilar mais.'

DP: Correto.

PF: 'Não haverá mais necessidade para estarmos solidários.' Penso que, no fundo, uma das lições mais importantes que os que convivem com a miséria, com a fome, com a abnegação possam dar aos que vivem na abundância seja precisamente que a solidariedade, além das condições nas quais nos descobrimos, nos faz...é uma necessidade que nos dá mais capacidade de sermos mais próximos de nosso ideal.

DP: Ela resgata o nosso lado humano.

PF: Creio que um dos nossos grandes erros da gente da esquerda, não somente no Brasil, seja pensar que, quando falamos de solidariedade, usamos um conceito, uma palavra burguês(a). Aliás, a burguesia não tem solidariedade. Ela seria uma falsidade ainda maior quando falassemos da necessidade de solidariedade aos trabalhadores ou ao povo vivendo na miséria, ao lado de um rio poluente. Penso que jamais na história da humanidade, teve tanta importância viver na solidariedade pois aqui, agora, ela é uma metáfora pela luta.

DP: É uma necessidade, uma motivação. Não acho que todas as nossas lutas, todo o trabalho que a gente faz, procura, estabelece, reivindica como a nossa identidade, como uma parte do nosso progresso humano seja sem valor, lenta e atrasada. Ao contrário, sinto a pressão criada por um grupo muito inteligente, a elite, que organiza e combina as coisas com muito mais velocidade da que é possível para nós. Digo isso com medo de estar errado, mas eles se movem com mais rapidez. Aliás, parece que a nossa articulação vai mais lenta pois somos uma massa enorme enquanto a situação dela, sendo um grupo pequeno, se move mais velozmente. 
Danilson Pinto parece estar confortável na sua pele em qualquer situação - seja debatendo um ponto num seminário de filosofia, seja supervisionando a formação dos instrutores num centro de trabalho na Zona da Mata, seja agitando uma faixa no Estádio Arruda, quando seu time favorito, o Santa Cruz, joga contra o Naútico. Um homem barbudo, intenso, enxuto, da cor de canela, que morou em Recife desde 1977, quando tinha dezesseis anos e fora escolhido para preparar-se para o sacerdócio como um representante da juventude nordestina na "Pastoral Jovem do Povo", um grupo católico romano. Ele se formou na Universidade Católica de Recife, em 1992, graduando-se em filosofia e, desde então, tem sido um educador popular. Trabalhou como assistente de João Francisco de Souza, quando este era Secretário de Educação em Olinda. Souza bem sabia que a força verdadeira de Danilson era dentro da sala de aula. Então, juntos, criaram as "Colônias de Férias" no CAIC, a maior instituição pedagógica de Olinda, no intervalo escolar de quinze dias, no tempo de carnaval. Muitas famílias empobrecidas dependem da merenda escolar diária que inclui café da manhã e almoço, para sobrevivência de suas filhas e seus filhos. O grupo alvo das "Colônias" estava na faixa etária de 11 a 14 anos de idade. Danilson organizou uma oficina artesanal durante a quinzena carnavalesca, com artesãos locais funcionando como instrutores e supervisionou as tentativas dos jovens de criarem xilografias, pôsteres, faixas e fantasias de carnaval, todas feitas de sucata e de outros materiais reciclados. Quando um jovem se queixara da dificuldade de fazer xilogravura, o instrutor lhe dizia: - "Seria difícil para mim não fazê-la."

Xilografia e xilogravura são especialidades olindenses e alguns jovens logo mostraram seus talentos. Edna, uma moça acanhada de treze anos, levou somente três horas para completar uma xilografia no dia em que recebeu as ferramentas. Seu instrutor reconheceu sua habilidade artística e encorajou-lhe a prosseguir com a carpintaria como carreira. Danilson observava que as relações entre instrutores e as/os alunas/os são cordiais, mas concentrados no trabalho. A produção incluía macacos e leões de papel machê, bois e jumentos dançantes, cujos corpos flexíveis de arame e papel jornal eram pendurados nos ombros de seus criadores. Vestiam chapéus e capas de várias cores e carregaram grandes lápis como lanças, enquanto desciam as ladeiras íngremes de paralelepípedos da velha cidade colonial, batendo tambores e zabumbas, cantando e dançando o frevo - uma dança ainda mais frenética do que o samba de rua, para a qual seus corpos elásticos e vigorosos pareciam feitos. Em Recife e Olinda, como em outros lugares empobrecidos e densamente povoados, o carnaval funciona como uma válvula de escape, de acordo com a teoria de Frantz Fanon, que atribui aos oprimidos uma espécie de ira contra o colonizador. 
Dominique Fernandez, um estudioso francês de arte e arquitetura, considerou "étonnant" (espantoso), quando visitara Olinda, que "as condições precárias da existência despertavam o instinto do povo pela beleza em vez de apagá-lo." Observando uma roda de capoeiristas, ensaiando num espaço escolar pavimentado, o professor Fernandez se maravilhara afirmando que "numa cidade tão pobre, longínqua e esquecida, onde o povo tem estado abandonado e flagelado pela sorte, ainda se prepara com tão completa paixão para executar uma forma de arte altamente sofisticada, somente pelo prazer"15 (1993, p. 155).

Um quarto século após a visita do eloquente doutor francês, o prazer se tornara dor. A cidade alta de Olinda, declarada pelas Nações Unidas um sítio histórico mundial, nos meados dos anos oitenta do século passado, tem tido seu patrimônio dilapidado por uma série de prefeituras municipais corruptas. A Sé do século XVIII, no pico da colina mais alta e com uma vista deslumbrante da vila colonial e do Oceano Atlântico, um monumento do mundo novo louvando as glórias arquitetônicas do mundo velho, é atualmente atormentada e degradada por uma onda aparentemente incontrolável de crime e de desespero, sob os efeitos malévolos de vários ciberentorpecentes, além de assolada pelos setecentos pecados da política de cobiça. Danilson Pinto fora absorvido pelas doutrinas filosóficas e espirituais da Santa Igreja Católica, pelo romantismo utópico de Paulo Freire e João Francisco de Souza, musicalmente, pelo anarquismo tribal dos Goths e dos Punks e pela energia solar do saudoso poeta e músico Chico Science e seu movimento Mangue Beat. A pedagogia de Danilson é combativa, disposta a lutar pela equidade educacional e pela justiça social num lugar difícil onde o sofrimento do povo é ubíquo. Mais que duas décadas depois de seu encontro com Paulo Freire na ponte do Cabo Gato, a situação no Brasil continuou bastante sombria. Segundo Danilson, a noção da solidariedade está desaparecida. Solidariedade começa quando as pessoas entendem que estão, ou devem estar, ligados por uma humanidade comum. Para afirmar a nossa interdependência e a nossa humanidade devemos lutar ombro a ombro com as pessoas que ainda estão procurando e brigando por seus direitos humanos e por sua qualidade humana. A maior dissuasão a essa unidade de propósito ocorre quando se nutre ou se ignora o nosso instinto interno de subjugar o/a outro/a. Achar as falhas e os defeitos do outro é um bom indicador de que meu crítico interno está cochichando ao meu ouvido. Enxergar uma pessoa abandonada ou viciada, morando na rua, e querer que ele ou ela desapareçam indica que meu opressor interno está se apoderando de mim. Danilson pensava que devemos nos livrar das nossas próprias vozes opressivas para poder sentir-nos aliados/as e sincronizados/as com as demais pessoas. Se não podemos fazer isso, diminuímos o sentido da alegria da vida que eventuamente cultivávamos. Assim, parece razoável que carreguemos armas para nos proteger dos outros/outras e, quando não mais 
pudermos tolerar a dor, optaremos pelo suicídio. Quando comparamos nossas vísceras agitadas com as aparentemente plácidas dos outros/as, é possível que nossa perspectiva esteja tão distorcida quanto nossos preceitos e princípios. Sentir autocomiseração, dor e remorso destrói qualquer impulso de cooperação.

Se o professor norteamericano George Stoney da Escola Tisch, da Universidade de Nova Iorque (NYU), tivesse realizado sua meta de fazer um filme documentário sobre a odisséia de Paulo Freire ${ }^{16}$, poderíamos fazer uma ideia de sua vida e da profundidade de sua obra. Contudo, a morte escolhera outros fins para ambos os homens - o de Freire, lamentávelmente, antes. Resta dizer que Professor Stoney, que faleceu com a idade de 96 anos, em 2012, inspirou-se nos livros de Paulo Freire, embora os tenha descoberto nos seus setenta anos de idade, e que houvesse renovado por completo sua vontade de continuar o ensinamento freiriano. Dedicou-se, de corpo e alma, à tarefa de retraçar os passos do "andarilho do óbvio", em lugares tão espalhados como Santiago do Chile, a vila sertaneja de Angicos, no Rio Grande do Norte, as ilhas cabo-verdeanas, Suíça, Nicarágua e Guiné-Bissau. Seu feito é, também, realmente impressionante.

Nos vestígios da filmagem feita em Olinda que eu assistira, a pele de Freire tivera de se tornar cor de chocolate sob o sol ardente da sua terra natal, enquanto Stoney se permaneça branquinho e um pouco desajeitado nos seus diálogos, conduzidos todos na língua inglesa. Por exemplo, parados em frente de uma igreja barroca, Stoney pergunta a Freire qual é sua comida predileta. Então Freire responde, talmudicamente, com uma outra pergunta: "Por quê os Americanos comem tantos piews?" Quando Stoney obviamente não entende a fala, Freire imita o ato de engolir um punhado de pilulas e Stoney ri. Talvez, o filme não fosse um successo de bilheteria, mas demonstraria uma amizade palpável entre os dois velhos guerreiros, que teria sido irresistível. Em todo caso, o romantismo utópico inclui a fascinação e o desejo de se estar perto do outro, dissipando-se, assim, as tendências isoladoras. O que o admirável poeta russo, Yevgeny Yevtushenko, chamou de "o micróbio obsceno da superioridade", que é uma toxina que o nosso planeta deve rejeitar.

O envolvimento pedagógico intenso do educador Jean-Jacques Rousseau com seu aluno, Émile; o artesão nobre William Morris, tomando o caso dos artesãos mais humildes na véspera da revolução industrial; a dedicação de João Francisco de Souza e Danilson Pinto à juventude e aos adultos analfabetos e semi-letrados de Olinda e Recife, como a de Paulo Freire anos antes, é exemplar nessa época da educação padronizada e motivada por lucro. Todos os sonhos dos românticos utópicos estão sendo negados e ameaçados. Ansiamos pelo companheirismo e pelo engajamento conjunto numa causa que nós permita lutar por um mundo melhor, aceitando 
nossas opções e nossos compromissos como escolhas morais. Que a utopia radical seja romântica por definição. Eis um romantismo que nos impulsiona para agir e refletir... e agir de novo, que vive nos corações e nas almas de toda a gente cuja alegria é de viver e servir em solidariedade com outras e outros, para superarmos o ceticismo e a cobiça e para gestarmos uma mudança duradoura na direção progressista e humana.

Los Angeles, 30 de junho de 2019.

\footnotetext{
${ }^{1}$ Revisão técnica e da tradução: José Eustáquio Romão.

${ }^{2}$ Buscando um exemplar de Pedagogia do Oprimido em português na Biblioteca de Pesquisas da University of California Los Angeles (UCLA), encontrei uma cópia amarelada mas intata do primeiro lançamento uruguaio, com prefácio de Ernani Maria Fiori, uma ocasião insólita no cinquentenário do livro.

${ }^{3}$ Professor de Souza morreu no dia 28 de março de 2008, nos arredores de Salvador, Bahia, enquanto tentava se defender durante um roubo armado na casa de um sócio acadêmico onde estava hospedado. Ele viveu 63 anos. Numa entrevista posta num sítio portuguesa sete meses após sua morte (http://www.direitodeaprender.com.pt/artigos/entrevista-com-joão-francisco-de-souza) declarara, "Se eu gero um processo em que as pessoas se sentem excluídas, não-amadas, se as necessidades básicas não são satisfeitas, elas têm todo o direito de me incomodar, no mínimo bater à minha porta e pedir uma esmola, uma ajuda. Você termina perdendo o que julgava que era o seu bem-estar individual, porque o outro está incomodando."

${ }^{4}$ Tradução Peter Lownds.

${ }^{5}$ Tradução Peter Lownds.

${ }^{6}$ Tradução Peter Lownds

${ }^{7}$ Tradução Peter Lownds.

${ }^{8}$ Um vilarejo rural quando a família Freire trasladou para lá no início da prontidão dos anos 1930, agora Jaboatão é um centro de atividade comercial e faz parte da grande área metropolitana de Recife.

${ }^{9}$ Tradução Peter Lownds.

${ }^{10}$ Charles Alexis Clérel de Tocqueville (1805-1859), autor Da democracia em América (1835) e O Regime Antigo e a Revolução (1850).

${ }^{11}$ Traduçao Peter Lownds.

${ }^{12} \mathrm{O}$ povo rural da Zona da Mata sempre lutava para um enterro decente [...] e eventualmente isto significara [...] "dois metros abaixo do próprio caixão". Este slogan tornou a ser o grito de guerra das Ligas Camponesas que adotaram como um dos seus primeiros projetos uma mobilização rural ao redor dos direitos de enterro pelos mortos em vez dos direitos dos vivos. "Antes das Ligas", explicou Zé de Souza, "quando a gente morreu, o caixão estava emprestado pelo município e, depois que carregaram o corpo à cova comum, o caixão foi devolvido ao armazém municipal. Hoje em dia, a Liga paga o funeral e o caixão está enterrado com o defunto dentro dele. Eis que a Liga nos fez" (SCHEPER-HUGHES, 1992, p. 253)

${ }^{13}$ Tradução Peter Lownds

${ }^{14} \mathrm{O}$ título do trabalho com que concorreu a uma cátedra na Faculdade de Belas Artes de Recife (mais tarde incorporada à Universidade Federal de Pernambuco, publicado postumamente, com a organização de José Eustáquio Romão, pelo Instituto Paulo Freire do Brasil e Editora Cortez, em 2001.

${ }^{15}$ Tradução Peter Lownds.

${ }^{16} \mathrm{O}$ video que contém o diálogo entre Paulo Freire e Danilson Pinto, nas páginas 17 e 18 deste ensaio, é apenas um fragmento do projeto.
}

\section{Referências}

ARENDT, Hannah. The Human Condition. 2. ed., Chicago: Universidade de Chicago, 1998

BEISIEGEL, Celso de Rui. Política e Educação Popular: a teoria e a prática de Paulo Freire no Brasil. São Paulo: Ática, 1982. 
BRANDÃO, Carlos Rodrigues (org.). A questão da política da educacão popular. São Paulo: Brasiliense, 1980.

COHN, Sergio (org.) Encontros: Paulo Freire. Rio de Janeiro: Beco do Azougue, 2012.

FANON, Frantz. The Wretched of the Earth. New York: Grove/Atlantic, 1988.

FERNANDEZ, Dominique. L'or des Tropiques: Promenades dans le Portugal et le Brésil baroques. Paris: Bernard Grasset, 1993.

FREIRE, Paulo. Education for Critical Consciousness. Tradução Myra Bergman Ramos, New York: Continuum, 1973.

FREIRE, Paulo. Pedagogy of Hope. Tradução Robert R. Barr, New York: Continuum, 1994.

FREIRE, Paulo Letters to Cristina. Tradução Donaldo Macedo, New York: Routledge, 1996.

FREIRE, Paulo. Cartas A Cristina. São Paulo: Paz e Terra, 1994b.

FREIRE, Paulo. Pedagogy of the oppressed, Tradução Myra Bergman Ramos, New York: Continuum, 2000.

FREIRE, Paulo. Pedagogía del oprimido. Montevideo: Tierra Nueva, 1970.

FREIRE, Paulo. Pedagogia da autonomia. 23. ed., São Paulo: Paz e Terra, 2002

FREIRE, Ana Maria Araújo. Paulo Freire: Uma história da vida. São Paulo: Cultura, 2006.

FREYRE, Gilberto. Casa-grande \& senzala. 43. ed., São Paulo: Record, 2001.

GADOTTI, Moacir. Os mestres de Rousseau. São Paulo: Cortez, 2004.

GADOTTI, Moacir. et al. (org.) Paulo Freire: uma biobibliografia. São Paulo: Cortez; IPF, 1996.

GILLON, Étienne et al. (directeurs) Nouveau Petit Larousse en couleurs. Paris: Larousse, 1968.

HOUAISS, Antônio; MILLAR, Mauro de Salles. Minidicionário Houaiss da língua portuguesa. Rio de Janeiro: Objetivo, 2009.

LOWNDS, Peter Michael. In the shadow of Freire: Popular Educators in Northeast Brazil. Doctoral Dissertation, UCLA Graduate School of Education \& Information Studies, 2006.

MAFRA, Jason, ROMÃO, J. E.; SCOCUGLIA, A. C.; GADOTTI, M. (org.). Globalização, educação e movimentos sociais. 40 anos da Pedagogia do Oprimido. São Paulo: Editora e Livraria IPF; Editora, 2009. 
MCLAREN, Peter; LEONARD, P. (ed.). Paulo Freire: a critical encounter. London: Routledge, 1992.

NASCIMENTO, Abdias. Thoth n. 2, maio/ago., 1997, Brasília: Secretaria Especial de Editoração e Publicações do Gabinete do Senador A.N.

NITTI, John J.; FERREIRA, Michael J. 501 Portuguese verbs fully conjugated. Hauppauge, N.Y.: Barron's Educational Series, Inc., 1995.

RANK, Otto. Art and Artist: creative urge and personality development. New York: Alfred A. Knopf, 1932.

RETAMAR, Roberto F. Caliban: apuntes sobre la cultura en nuestra América. 2. ed. México, D.F.: Diógenes, 1974.

ROSAS, Paulo. Como vejo Paulo Freire. Recife: Secretaria de Educação, Cultura e Esporte, 1991.

ROUSSEAU, Jean-Jacques. Émile or on education. New York: Basic Books, 1979.

SCHEPER-HUGHES, Nancy. Death without weeping: The violence of everyday life in Brazil. Berkeley; Los Angeles: University of California Press, 1992.

SHAKESPEARE, William. The Tudor edition of the complete works. London; Glasgow: Collins, 1951.

STONEY, George C. Unfinished video documentary about Paulo Freire (begun in 1995).

STRECK, Danilo R. Educação para um novo contrato social. Petrópolis: Vozes, 2003.

TAYLOR, Paul V. The texts of Paulo Freire. Buckingham: Open University Press, 1993.

THOMPSON, E.P. William Morris: romantic to revolutionary. London: Lawrence \& Wishart, 1955.

TORRES, Carlos Alberto. Diálogo com Paulo Freire. São Paulo: Loyola, 1979.

WERNER, Camila (ed.). Dicionário Larousse Inglês/Português.Português/Inglês Avançado. São Paulo: Larousse do Brasil, 2009. 